\title{
Incidental Finding of Placenta Increta in a Patient with Vaginal Bleeding Refractory to Medical Treatment
}

\author{
Tod J Rothschild*, Tatiana Viloria, Ann Chernys, Usha Pulakhandam and Alexandr Fuks \\ Mount Sinai School of Medicine, USA
}

Submission: June 08, 2017; Published: July 27, 2017

*Corresponding author: Tod J Rothschild; Mount Sinai School of Medicine, USA, Email: ROTHSCHT@nychhc.org

\section{Introduction}

Placenta increta can be a life threatening obstetrical complication. Although most commonly diagnosed in second and third trimester upon difficult placental removal and post partum bleeding, there have been several first trimester cases reported. These cases by and large present with vaginal bleeding and/ or hemorrhage. They can present both immediately after instrumental abortions or curettage, and weeks to months after spontaneous abortions. Part of the difficulty in diagnosing and treatment of this clinical scenario in the first trimester is its rarity. Approximately 1: 2500-7000 placental pathologies are accreta, increta and percreta in nature. These only represent reported cases, and since first trimester findings are the least common, it is unclear what percentage they import. The abnormality in the placenta [1] that leads to increta is the absence of the decidua basalis and imperfect development of the fibrinoid layer, also known as the Nitabuch Layer.

\section{Case Report}

A 28 - yr-old woman, gravida 6, para 2, 0, 4, 2 with last menstrual period starting 10 days prior, reported to the emergency room complaining of weakness and dizziness and heavy vaginal bleeding. Her obstetrical history was significant for one spontaneous abortion 6 months prior, three elective terminations via dilation and curettage, one full term vaginal delivery and one full term low transverse c-section for abnormal lie. She reported heavy and irregular menses, as of three months prior to her presentation. At evaluation in the emergency room, vitals were BP 100/62, Pulse 107, Temp 98.2 f, RR 18 and oxygen sat. $100 \%$. Minimal bleeding was noted on speculum exam and uterus was approximately, 8 week size, anteverted and non tender. Adnexa were non tender and non palpable. Hemoglobin/ hematocrit count, 7.7/22. UCG and BHCG were negative. Two days prior the patient was seen in the emergency room with similar complaints. At that time vitals were stable, hemoglobin/ hematocrit was 8.3/25.6 and she was therefore discharged home with an oral contraceptive cascade. She was admitted, given two units of packed red blood cells and oral contraceptives to help control the bleeding. Her bleeding stopped and discharge plans were considered 36 hours later. Her vitals were and she had no complaints of bleeding. She suddenly began to bleed heavily and had loss of consciousness. An RRT (rapid response team) was called. Her BP was $80 / 50$ and her pulse was 130 . She was bleeding heavily. 2 units of PRBC were given and she was taken to the OR for a dilation and curettage. During the d\&c some tissue was obtained, however the patient continued to bleed briskly. The bleeding appeared to be originating from the lower uterine segment. PRBCS and FFP were given intraoperatively and a BAKRI balloon was inserted to tamponade the bleeding site. The patient continued to bleed briskly and the decision was made to do an exploratory laparotomy and supracervical hysterectomy. The patient received additional PRBCs, FFP, and platelets secondary to a clinical diagnosis of DIC. The patient was transferred to the ICU postoperatively for 24 hours. She was discharged home on POD \#4 in good condition. The final pathology revealed placenta increta (Figure $1 \& 2$ ).

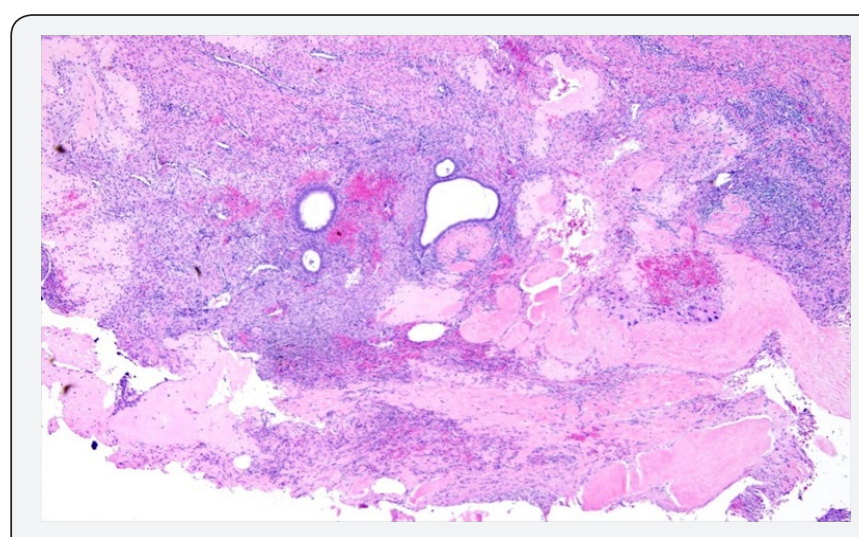

Figure 1: Sclerotic Villi and Endometrial Surface. 


\section{Global Journal of Reproductive Medicine}

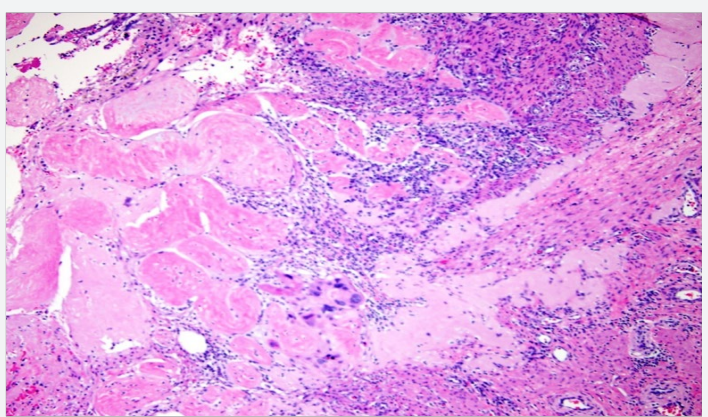

Figure 2: Sclerotic Villi in Smooth Muscle with Trophoblasts.

\section{Discussion}

This is a very rare presentation of placenta increta 5 months after spontaneous abortion [2]. Although there was only a few cases reports $(1,2,3)$ in the literature, this possibility should be considered when there is refractory uterine bleeding under the following circumstances:

1. History of previous cesarean

2. Recent pregnancy loss or termination

3. Refractory to hormones

Currently there is no imaging modality availability which could assist in the diagnosis.

\section{References}

1. Takeda A, Kazuyuki $K$, Imoto S, Mori M, Nakano T, et al. (2010) Conservative management of placenta increta after first trimester abortion by transcatheter arterial chemoembolization: a case report and review of the literature. Archives of Gynecology and Obstetrics 281(3): 381-386

2. Son G, Kwon J, Cho H, Kim S, Yoon B, et al. (2007) A Case of Placenta Increta Presenting as Delayed Postabortal Intraperitoneal Bleeding in the First Trimester. J Korean Med Sci 22(5): 932-935.

\section{Your next submission with Juniper Publishers will reach you the below assets}

- Quality Editorial service

- Swift Peer Review

- Reprints availability

- E-prints Service

- Manuscript Podcast for convenient understanding

- Global attainment for your research

- Manuscript accessibility in different formats

( Pdf, E-pub, Full Text, Audio)

- Unceasing customer service

Track the below URL for one-step submission https://juniperpublishers.com/online-submission.php 